\title{
O REi está nu. CONTRAPOdER E REALizaÇÃo DE DESEJO, NA PIADA E NO HUMOR
}

\author{
Joel Birman*
}

\section{Resumo}

A finalidade deste artigo é a de demonstrar como a piada e o humor têm como alvo privilegiado o campo do poder, sendo assim práticas discursivas eminentemente sociais. Além disso, como formas que seriam de realização de desejo, segundo Freud, seriam ainda formas de desconstrução do poder.

Palavras-chave: contrapoder, social, desejo.

\begin{abstract}
The KING IS NAKed. Counter POWER AND WISHFul thinking IN JOKe AND HUMOR

The aim of this paper is to demonstrate that joke and humor have power as their privileged target, by which they become social discourse practices. Besides that, as forms of wishful thinking, according to Freud, joke and humor could be a way of deconstructing power.

Keywords: counter power, wishful, humor.
\end{abstract}

\section{TEMOR E TERROR}

No tempo em que exercia a Presidência da República do Brasil, Fernando Henrique Cardoso formulou um comentário curioso num de seus discursos, que é bastante revelador do lugar estratégico ocupado pelo humor na sociedade contemporânea. Assim, entre o tom jocoso e a seriedade efetiva, onde as fronteiras

* Psicanalista; Professor Titular do Instituto de Psicologia da Universidade Federal do Rio de Janeiro (UFRJ); Professor Adjunto do Instituto de Medicina Social da Universidade do Estado do Rio de Janeiro (UERJ); Pesquisador associado do Laboratório de Psicanálise e Medicina, Universidade Paris VII. 
se esmaecem na delimitação dos seus domínios respectivos, no qual a ironia se transmuta magicamente em autoironia, o ex-Presidente do Brasil dizia que ficava sempre apreensivo pelas manhãs, antes da leitura dos jornais do dia, para ler a charge de Chico Caruso, em $O$ Globo. Isso porque precisava ver e verificar se tinha sido transformado em personagem de galhofa pelo humorista e avaliar ainda se tinha sido ridicularizado por algo que teria dito e feito no dia anterior, no exercício soberano de sua função pública.

Referia-se então especificamente a Chico Caruso, pois o seu pronunciamento se realizava no Rio de Janeiro, numa cerimônia em que recebera o título de Doutor Honoris Causa, concedido pela Universidade Cândido Mendes. Porém é óbvio que a sua inquietação face aos cartunistas não se restringia nem ao $O$ Globo, nem tampouco a Chico Caruso, mas se disseminava a todos os demais jornais do país, nos quais poderia ser alvo de um comentário jocoso da parte de qualquer um dos humoristas.

Portanto, o que estava aqui em pauta era como um dizer e um fazer, isto é, um ato qualquer do Presidente da República, poderia simplesmente ser reduzido ao ridículo pelo desenho e pelas poucas palavras rascunhadas pelo humorista. Com efeito, por um simples traço colocado em relevo - seja uma boca, os olhos, uma das mãos ou mesmo a cabeça um pouco distorcida -, conjugado a uma simples frase mal dita, seria toda a pompa solene representada pelo personagem do Presidente da República que seria nocauteada e reduzida a frangalhos pelo olhar sutil e irônico do humorista. Enfim, numa fração de segundos a figura quase sagrada do Presidente do Brasil seria lançada à sarjeta, abatida como um pássaro no seu voo supremo, pelo comentário ardiloso do humorista.

Seria justamente a eventualidade desta simples possibilidade o que obcecava cotidianamente Fernando Henrique Cardoso no exercício efetivo de sua função pública. Poder-se-ia arguir inicialmente se não se tratava de uma vaidade excessiva do personagem em questão, preocupado de tal maneira com a sua imagem, pois como é que um homem tão importante e poderoso como ele poderia se sentir tão atingido por uma simples brincadeira e até mesmo por uma molecagem de um caricaturista? Contudo, mesmo que se queira considerar a dimensão de vaidade específica do ex-Presidente da República, no caso em questão, ao ser flechado pelo comentário de bico-de-pena do chargista, existe no que tange a isso algo que transcende em muito a mera vaidade do personagem em pauta.

Do que se trata, afinal das contas? Qual é a vaidade que está aqui em questão? Por que tal temor e tanto temor da parte de um personagem tão importante e poderoso? 


\section{Somos TODOS IGUAIS?}

Assim, o que o humorista coloca em cena, no seu desenho sempre marcado pela ironia, é a redução de uma figura do poder à condição de simples mortal, isto é, de alguém que é igual a qualquer um de nós que olha maliciosamente a caricatura e que certamente se delicia com ela. Porém, se o leitor ri às gargalhadas e se diverte muito com a charge, isso se deve precisamente à constatação de que todos os homens poderosos são como nós, afinal das contas. Vale dizer, não existiria qualquer diferença efetiva e substancial entre os detentores do poder e os demais cidadãos que pudesse oferecer para aqueles qualquer destaque ontológico entre os humanos.

Ao lado disso, se Fernando Henrique Cardoso sofria com a antecipação e a efetividade da caricatura, isso quer dizer que ele sabia perfeitamente que poderia ser colocado subitamente no seu devido lugar, isto é, nem melhor nem tampouco pior do que todos os demais. Seria, assim, esta possibilidade concreta de ser equalizado por baixo o que fazia sofrer o nosso Príncipe de então e o obcecava todas as manhãs, detentor que era da soberania da sociedade política brasileira. Portanto, Fernando Henrique Cardoso se angustiava efetivamente com a antecipação de uma caricatura que o faria se defrontar com a sua condição real, sem o revestimento mágico da aura conferida pelo exercício majestático do poder soberano. Estaria justamente aqui a razão do seu tormento cotidiano, ao ter que admitir, no lusco-fusco de um olhar furtivo lançado à caricatura, a sua igualdade com os demais homens. Enfim, seria pela possibilidade de sermos igualmente ridicularizados que podemos atingir efetivamente a almejada condição de igualdade, pois as fraquezas e as debilidades humanas seriam os únicos bens que poderiam ser igualmente distribuídos entre os cidadãos, de maneira ampla, geral e irrestrita, numa sociedade democrática e republicana.

Assim, entre a gargalhada estridente do cidadão comum e a angústia do Príncipe, o que está em pauta é a mesma problemática, que engloba esse e aquele na mesma ilusão. No entanto, se existe aqui uma ilusão que é compartilhada, é preciso que essa seja devidamente enunciada. Neste compartilhamento, com efeito, existe a crença de que quem exerce o poder adquire uma superioridade sobre os demais cidadãos e de que aquele valeria mais ontologicamente, por conta disso.

Portanto, no caso em questão o que está em causa é o poder político, que está condensado na figura do Presidente da República do Brasil. Porém poderia ser o poder político em qualquer outra de suas instâncias, seja essa estadual ou municipal. Além disso, poderia ser qualquer outro exercício político do poder, nos registros do Executivo, do Legislativo e do Judiciário. Enfim, poderia ser ainda qualquer outra representação do poder, nos registros institucional e empresarial. 
É claro que existe uma hierarquia efetiva entre estas diferentes instâncias de poder, seja esse de ordem política ou de ordem social. Porém, quanto mais elevada é a inserção de um dado cidadão no campo da hierarquia do poder, maior será a sua aura e a sua condição majestática. No entanto, é óbvio que qualquer poder na modernidade é sempre relativo, em decorrência do equilíbrio existente entre as diferentes instâncias do poder.

No que concerne ao poder político no Brasil, como se sabe, o poder condensado na Presidência da República é bem mais elevado do que ocorre em outras tradições políticas, onde a república como tradição está instituída. Isso é a decorrência do desequilíbrio real existente entre os poderes Executivo, Legislativo e Judiciário, mesmo que o equilíbrio formal entre esses esteja estabelecido constitucionalmente.

De qualquer forma, no campo do imaginário do cidadão comum toda e qualquer posição de poder coloca sempre em destaque aquele que desempenha e ocupa momentaneamente a função em causa. Isso porque o cidadão separa quem o exerce do campo comum da cidadania. Tudo se passa como se o dito cidadáo esquecesse que uma posição política de poder, numa sociedade democrática, é sempre uma delegação de poder. Em conjunção com isso, pode-se dizer ainda que quem ocupa a posição de poder se esquece também de sua condição de igualdade com os demais, passando assim a acreditar que seja possuidor de algo a mais de que os demais cidadãos não seriam detentores.

Portanto, seria essa crença compartilhada, no registro da ilusão, o que cai literalmente por terra pelo exercício do humor. Esta queda é vertiginosa, por um lado, e exaltante, pelo outro. Vertiginosa, no polo do Príncipe, e exaltante, no polo do cidadão comum. Com efeito, se o Príncipe se angustia ao antever a possibilidade de ser ridicularizado, a massa fica eufórica com a queda da pretensão do Príncipe. Com isso, a gangorra retorna momentaneamente ao ponto inicial de equilíbrio entre o Príncipe e a massa de cidadãos, pela prática do humor, se opondo, assim, ao desequilíbrio hierárquico existente entre esses no campo do imaginário social.

Deste modo, a experiência do humor revela ao cidadão comum que o Príncipe é ontologicamente igual a ele, submetido que é também aos mesmos limites e às mesmas prerrogativas colocadas pela existência. Ao lado disso, o humor na sua ironia destitui o Príncipe de sua aura majestática, enunciando como esse seria também "humano, demasiadamente humano", parafraseando Nietzsche ([1878] 1968). Enfim, são a ilusão e a hierarquia estabelecidas entre o Príncipe e a massa que são momentaneamente esvaziadas, restabelecendo então, num instante fulgurante, a estrutura política da moderna cidadania, pela qual todos os cidadãos são iguais diante da lei e o exercício do poder político passa necessariamente pela delegação e pela representação. 
Não obstante isso, no campo do imaginário social o cidadão comum acredita na onipotência do ocupante momentâneo do poder, pois supõe que esse possa seja lhe agraciar, seja lhe prejudicar pelas políticas públicas que promove. Ao lado disso, quem exerce o poder acredita igualmente na sua diferença hierárquica face ao cidadão comum, pelas políticas que escolhe e decide realizar.

Seria por conta disso, aliás, que o cidadão comum concebe sempre o poder como uma ameaça permanente para a sua vida, que pode conduzir o Príncipe em direção à tirania, na medida em que esse pode afetar, pelas suas decisões políticas, a sua existência pública e privada. Em contrapartida, no campo do imaginário político, a figura do Príncipe acredita igualmente que pode fazer o que quiser e bem entender, pela aura que lhe é conferida. Daí porque a corrupção é um dos males maiores que pairam sempre sobre o campo do poder, pois o Príncipe supóe frequentemente que detém um poder onipotente sobre os cidadãos e não uma função política que lhe foi atribuída, por delegação dos cidadãos.

Nesta perspectiva, o humor tem a potência de promover a ruptura no registro do imaginário social e de reenviar momentaneamente, tanto o cidadão comum e quem exerce o poder, para a sua igualdade fundamental, de acordo com os imperativos jurídico-políticos da sociedade democrática e republicana. A risada irônica do leitor da charge seria, assim, resultante do alívio, que toma o cidadão de corpo inteiro, ao redescobrir e ao relembrar que a sua humanidade tem a mesma densidade do que a do Príncipe. Em contrapartida, o tormento do Príncipe face ao humor é o de reconhecer o que sempre soube, qual seja, de que está em pé de igualdade com qualquer outro cidadão, sem tirar nem pôr. Enfim, o humor tem a potência de nos evocar de maneira insistente que somos todos equivalentes nas nossas diferenças, relançados que somos por aquele à mesma sopa comum da cidadania, sem os ouropéis dos poderosos e sem a indigência dos cidadãos comuns.

\section{IMORTALIDADE EM QUESTÃO}

Vale evocar ainda aqui uma outra saga humorística sobre o poder político no Brasil contemporâneo, pelo efeito significante que promoveu o comentário irônico do chargista.

Assim, indicado que foi para ser o primeiro Presidente da República pelo seu perfil marcadamente conciliador, após os anos de chumbo da Ditadura militar e por um acerto político entre as elites de então, Tancredo Neves acabou por adoecer, de uma doença que o conduziu à morte, de maneira inevitável. Tratava-se de uma diverticulite que se complicou bastante, pois, para não tornar pública a sua 
doença e inviabilizar a sua indicação política à Presidência da República, Tancredo Neves se automedicou com antibióticos. Em decorrência disso, seu estado clínico se complicou bastante, quando esse teve que ser hospitalizado e a Nação brasileira acompanhou atordoada o seu martírio. Diariamente, então, os jornais e os telejornais noticiavam o tempo todo as condições clínicas do político em questão pela leitura dos boletins dos especialistas que dele cuidavam.

Ninguém sabia ao certo o que poderia acontecer, pois os boletins médicos eram sempre tranquilizadores. Ao lado disso, os médicos responsáveis pela sua assistência deram entrevistas frequentes para tranquilizar a população ansiosa com a condição clínica real do político. Porém esse acabou por falecer após um longo martírio, morte essa que provocou uma grande comoção nacional.

Isso porque a investidura de Tancredo Neves na Presidência da República representava o retorno à ordem democrática da Nação e a sua morte seria então uma ameaça ao retorno da democracia ampla, geral e irrestrita. Esta ameaça tomava corpo porque o vice-presidente escolhido, José Sarney, seria o candidato à sucessão de Tancredo Neves no caso de sua morte e era um representante importante do Antigo Regime ditatorial.

Porém, durante o longo martírio de Tancredo Neves, o humorista Millôr Fernandes forjou um comentário de grande ousadia, evidenciando com isso que era um humorista de longo coturno. Assim, numa manhã pode-se ler num jornal a seguinte formulação: "é possível dizer tudo no Brasil, hoje, menos que até aqui morreu Neves". Evocando então um velho ditado brasileiro - "até aqui morreu Neves" -, Millôr Fernandes tocava com mestria naquilo que estava interdito, nos imaginários popular e político ao mesmo tempo, qual seja, a possibilidade real da morte de Tancredo Neves. Desta maneira, o humorista tornava evidente e patente a possibilidade efetiva da morte desse.

Assim, a condição efetiva de Tancredo Neves se fez então presente para todos, de maneira ao mesmo tempo irônica e espetacular, provocando a risada geral de seus leitores. Isso porque a possibilidade da morte do político estava presente para todos, certamente, mas de maneira virtual e recalcada. A piada forjada por Millôr Fernandes teve o impacto significante de promover a suspensão do recalque e de exibir a céu aberto a grande angústia brasileira do momento diante dos olhos e dos ouvidos do respeitável público, isto é, do conjunto de cidadãos da Nação.

A risada estridente do leitor da charge em pauta teve o sentido e o impacto de aliviar a angústia que estava presente no tormento público em relação ao político, levando-o a reconhecer a possibilidade efetiva da morte de Tancredo Neves, com todos os sonhos que a isso estavam relacionados, isto é, o retorno pleno da ordem democrática no Brasil. Ao lado da descarga catártica de angústia, a piada 
do humorista teve ainda o efeito significante ao possibilitar ao leitor uma outra visada sobre o campo político, conduzindo-o a pensar em outras alternativas para o imbróglio institucional em questão.

No entanto, se no exemplo paradigmático de Fernando Henrique Cardoso o que estava em pauta era a vergonha do Príncipe, no qual esse perde a sua aura e sua superioridade face ao cidadão comum, no exemplo de Tancredo Neves o que estava em questão, em contrapartida, era a igualdade de condição entre o Príncipe e o cidadão no que concerne as suas relações com a vida e com a morte. Vale dizer, não apenas somos todos iguais diante da lei, mas também somos iguais face à vida e à morte. Com efeito, a ironia cáustica e fulgurante que se faz presente na piada de Millôr Fernandes nos conduz a reconhecer que o poder não passa de uma ilusão frente à morte, pois não confere a imortalidade à figura do Príncipe. A pretensão à imortalidade é uma ilusão constitutiva do poder, pois todos somos mortais. Enfim, pela alusão ao "até aí morreu Neves", Millôr Fernandes forjou uma instigante paródia sobre a imortalidade do Príncipe e do poder, tocando, assim, na vaidade maior que se encontra inscrita no campo do imaginário social sobre o poder.

\section{Poder ACOSSADo}

Portanto, pode-se afirmar, então, sem pestanejar em nenhum instante, que o campo do poder político, nas suas diferentes formações e instâncias no espaço social, está no centro da experiência do humor nas sociedades democráticas modernas. Nestas, onde os indivíduos são efetivamente marcados pela igualdade de direitos face à lei e onde todos são cidadãos, o humor é uma modalidade de discurso pela qual esta igualdade é insistentemente evocada, principalmente quando no campo do imaginário social existe uma tendência para estabelecer signos de distinção social e de diferenças ontológicas entre as individualidades. Seria justamente por conta disso que o poder político, no seu sentido estrito, é o alvo privilegiado para a produção da piada e o campo de escolha para o exercício do humor nas suas diversas modalidades. Desta maneira, a produção da vergonha estaria no centro do efeito subjetivo do humor, pela mediação da qual se procura ridicularizar a pretensão de superioridade, de quem quer que seja, no exercício do poder.

Nesta perspectiva, o que estaria em pauta nos temores de Fernando Henrique Cardoso face aos cartunistas não é a sua suposta vaidade enquanto sujeito e singularidade, mas a aura de majestade que estaria sempre associada ao exercício do poder soberano. Estaria justamente aqui o alvo privilegiado do humor e da piada, que perseguem assim, literal e insistentemente, os poderosos. 
Pode-se enunciar deste modo que, pela produção do humor e da piada, o Príncipe seria despido de seu manto sagrado, de sua maquilagem forjada de maneira travestida e de seu colorido majestático, reduzido aos andrajos do cidadão comum. Vale dizer, o que se pretende mostrar é a nudez do Príncipe, que se evidencia na mortalidade do seu corpo e na sua precariedade simbólica. Enfim, o que se deseja é a mostração em ato de que o Rei está $n u$, pela dramaturgia tragicômica e ostensiva do humor e da piada.

Seria por conta disso, aliás, que nos regimes totalitários as práticas públicas do humor e da piada são ostensivamente proibidas pelo poder político, devendo essas se disseminar de forma clandestina. Isso porque, em tais regimes políticos, existe um culto hierárquico e hierático do poder, que não suporta estabelecer e reconhecer a igualdade de condições entre o Príncipe e a massa. Portanto, não seria possível mostrar que o Rei está nu, neste contexto sociopolítico, sob a pena de, quem o fizer, ser preso e mesmo ser morto pelo aparelho de segurança do poder político.

Há poucos anos um jornal na Dinamarca publicou algumas charges sobre Maomé, que foi assim delineado de maneira irônica. O que se visava, com isso, era o fundamentalismo muçulmano, que já se disseminava em escala internacional. Esta publicação, contudo, foi o alvo de críticas azedas da comunidade muçulmana, que se sentiu frontalmente ofendida enquanto sistema religioso. Pretendeu-se silenciar então o jornal em questão pela ousadia de sua blasfêmia, como se a figura histórica do profeta Maomé estivesse acima do Bem e do Mal. Enfim, para aquela comunidade política e religiosa o editor de jornal em questão teria que se retratar publicamente, gerando uma grande polêmica internacional sobre a liberdade de imprensa.

Da mesma forma, nos tempos duros da Ditadura militar no Brasil, a censura à imprensa se desdobrava na censura sistemática das páginas humorísticas dos jornais, revistas, programas de rádio e de televisão, assim como no teatro e no cinema. As publicações humorísticas, como o jornal “O Pasquim”, eram regularmente censuradas pelo poder militar, que não suportava a exibição pública de suas entranhas pela fina ironia presente nas partituras humorísticas.

Portanto, poder mostrar que o Rei está efetivamente nu, exibindo ostensivamente a face ridícula do Príncipe e a sua mortalidade, pelo exercício insistente do humor, é uma forma legítima de experiência democrática e republicana, pelo qual a igualdade da condição da cidadania é permanentemente evocada e ritualizada no espaço social. Enfim, pelo humor e pela piada o poder, nas suas diferentes formas e instâncias, fica momentânea e efetivamente acossado. 


\section{Desejo E INCONSCIENTE}

Pode-se depreender facilmente, com o percurso que realizamos até agora, como o humor e a piada são práticas eminentemente sociais. Vale dizer, não existiriam tais práticas fora do espaço social, que delineia o campo concreto e a interlocução efetiva para o humor e para a piada. Desta maneira, os espaços da intimidade absoluta e o do silêncio se opõem radicalmente aos enunciados humorísticos e chistosos, que não apenas são práticas discursivas como também se inscrevem efetivamente na cena social.

Em duas obras fundamentais de referência sobre a piada e o riso, tanto Freud quanto Bergson sustentaram esta formulação teórica de diferentes maneiras.

Para Bergson ([1900] 1983), em O riso, livro publicado em 1900, a prática do rir visaria restaurar a dimensão temporal da vida e da existência social, que estaria coibida e sufocada pelo predomínio da dimensão do espaço nos laços sociais. Assim, pela gargalhada estridente a descontinuidade seria produzida efetivamente no sujeito, no campo da sua existência social, de maneira a promover rupturas na continuidade e na regularidade do espaço, numa lógica marcada eminentemente pelo tempo.

Para Freud ([1905] 1969), em contrapartida, em O chiste e suas relaçôes com o inconsciente, obra publicada em 1905, seria necessária a existência de pelo menos três personagens para a produção da cena do chiste. Nessa cena, com efeito, duas personagens estariam necessariamente presentes, enquanto a terceira, em contraponto, ocuparia uma posição virtual. Neste contexto, uma primeira personagem fala para uma outra algo da ordem do risível e de irônico a propósito de uma terceira personagem. Vale dizer, duas personagens estabelecem juntas uma aliança para gozarem às custas de uma terceira, que seria depreciada e ridicularizada pelas duas primeiras. Enfim, a terceira personagem seria transformada em objeto de gozo para quem conta e para quem escuta a piada.

Nesta perspectiva, a piada teria então uma configuração eminentemente triangular, que definiria a sua estrutura (Freud, [1905] 1969). É claro que a personagem para quem se conta a piada pode ser múltipla, englobando uma grande plateia e mesmo toda a população. Porém, mesmo assim, a estrutura triangular se mantém sempre incólume, sem qualquer alteração e transformação. Seria esta triangulação o que definiria a condição concreta de possibilidade para a elocução da piada.

Porém, se Bergson ([1900] 1983) enfatizou no riso o imperativo da temporalidade para promover a ruptura da mecanização espacial presente no campo social, que seria assim crucial para of fuxo da vida, para Freud ([1905] 1969) o que estaria em questão na piada, em contrapartida, seria a realização do desejo. Para o discurso 
freudiano, portanto, o fluxo da vida, na sua duração eminentemente temporal, implicaria na mise-en-scène do desejo.

Assim, ridicularizar ironicamente alguém e gozar às custas de sua depreciação seria uma modalidade de realização do desejo, que se materializaria pela descarga da pulsão (Freud, [1905] 1969). A explosão estridente do riso, que o enunciado da piada necessariamente promove, seria a trilha pela qual a realização do desejo se forjaria. Estaria aqui a dimensão econômica da piada, que se acoplaria intimamente à dimensão semântica, que seria forjada na narrativa da piada (Freud, [1905] 1969). Face e verso que seriam de uma mesma problemática, as dimensóes econômica e significante da piada se conjugariam devidamente, sem fissuras e sem fendas.

Baseando-se na sua então recente teoria da sexualidade, Freud ([1905] 1962) retomou na sua leitura da piada as teses enunciadas nos Três ensaios sobre a teoria da sexualidade, obra que foi publicada igualmente em 1905. Antes de mais nada, a tese é de que a experiência sexual implicaria num prazer preliminar e num prazer final; o prazer preliminar promoveria o incremento das intensidades das pulsões sexuais para se desdobrar finalmente no orgasmo. Portanto, numa comparação eminentemente metafórica, a piada estaria para o prazer preliminar da mesma forma como o riso estaria para o orgasmo, numa metáfora que implicaria, no entanto, a materialidade da pulsão (Freud, [1905] 1962).

Em seguida, a tese enuncia que o prazer preliminar se inscreve no registro da sexualidade perverso-polimorfa (Freud, [1905] 1962). Assim, a piada seria cadenciada pelo polimorfismo da sexualidade infantil (Freud, [1905] 1969), outra maneira de o discurso freudiano enunciar a dimensão perversa da sexualidade e a parcialidade da pulsão como o seu substrato efetivo. Portanto, o prazer preliminar produzido pela piada se inscreveria no campo da sexualidade perverso-polimorfa, que delinearia a sua cena no registro do inconsciente.

Finalmente, a leitura da piada como realização de desejo seria uma terceira tese, que conjugaria as duas teses anteriores. Com efeito, a realização do desejo se basearia nas trilhas estabelecidas pela sexualidade perverso-polimorfa que possibilitariam a erogeneidade do movimento desejante. Enfim, a realização do desejo se fundaria sempre na dita sexualidade infantil.

No entanto, a questão que se impõe agora é a de se indagar sobre a especificidade da realização de desejo presente na piada, na sua diferença específica face às demais modalidades existentes de realização de desejo, na medida em que essa seria crucial no funcionamento do aparelho psíquico. É o que veremos agora, no que se segue. 


\section{Cena PSíQuiCa, CENA SOCIAL E FORMAÇôES DO INCONSCIENTE}

Assim, se o imperativo da realização de desejo seria fundamental no psiquismo delineado pelo discurso freudiano, isso se deve ao lugar estratégico conferido por esse discurso ao princípio do prazer. Esta formulação axial foi enunciada pelo discurso freudiano desde o seu início, em o "Projeto de uma psicologia científica" (Freud, [1895] 1973) e $A$ interpretação dos sonhos (Freud, [1900] 1967).

Tal tese sobre o primado do princípio do prazer continuará a ter a sua importância crucial no discurso freudiano mesmo posteriormente, quando Freud ([1920] 1987) enunciou a existência de um "Além do principio do prazer". Isso porque, na nova oposição entre os registros da pulsão de vida e da pulsão de morte, o princípio do prazer que regularia a pulsão de vida procuraria realizar a ligação da pulsão de morte. De forma que, neste contexto, a realização de desejo seria a forma pela qual a vida como potência se afirmaria face à demanda da morte, num diapasão sempre regulado pelo imperativo do princípio do prazer.

Assim, no psiquismo permeado pelo conflito entre as potências de vida e de morte, no qual a vida buscaria se impor face à morte, o princípio do prazer e a realização de desejo, como o seu correlato, seriam os operadores da afirmação da potência da vida. Daí por que o desejo ocupa uma posição tão estratégica no psiquismo descrito pelo discurso freudiano.

Dito isso, é preciso destacar agora como o discurso freudiano esboçou uma cartografia para as formas de realização de desejo pelo sujeito. Tal cartografia tem uma característica efetivamente sistemática, se considerarmos a regularidade pela qual as diferentes modalidades de realização de desejo se inscrevem no psiquismo, por um lado, e como tais formas de realização do desejo se concatenam entre elas, pelo outro.

Assim, do sintoma (Freud, [1896] 1973) à piada (Freud, [1905] 1969), passando pelo sonho (Freud, [1900] 1967), o lapso (Freud, [1901] 1973) e o ato falho (Freud, [1901] 1973), o que estaria sempre em pauta, nestas diferentes formas da produção psíquica, seria a realização de desejo. Por isso mesmo, Lacan ([1953] 1966) denominou estas produções psíquicas de formaçôes do inconsciente, pelas quais o sujeito realizaria o seu desejo, na medida em que o registro psíquico do inconsciente estaria fundado no desejo.

Porém pode-se depreender com facilidade que a relação entre a cena psíquica, fundada no desejo, e a cena intersubjetiva e a cena social não seria da mesma ordem nas diferentes formações do inconsciente. Do solipsismo à interlocução, diferentes cenários aqui se configuram nas diversas formações do inconsciente. Além disso, a articulação entre as diferentes formações em questão e a efetividade 
de um ato propriamente dito se delinearia de diferentes maneiras em cada uma destas formações psíquicas.

Como vimos, na piada a cena psíquica e a cena social se articulam intimamente, sem que exista qualquer ruído. Isso porque a cena social seria fundamental para a realização do desejo, que se inscreve na cena psíquica. Nessa conjunção, além disso, um ato efetivo lhe é consubstancial, pois a simples narrativa da piada provocaria de imediato o seu efeito no outro.

É claro que, nas diferentes formaçôes do inconsciente, existe sempre o endereçamento de uma palavra ao outro, pelo que o outro é invocado e evocado. Vale dizer, existe sempre uma Outra cena que se inscreve nas diferentes formações do inconsciente, no campo da qual o sujeito inscreve e dirige a sua mensagem. Mesmo que essa não se enuncie de forma simples e clara, mas opaca e cifrada, uma palavra é sempre dirigida ao outro para que se promova psiquicamente uma formação do inconsciente. Enfim, na sua radicalidade uma formação do inconsciente não seria nunca uma experiência solipsista, mas sempre alteritária e que visaria sempre um diálogo intersubjetivo.

Assim, pela produção de um sintoma o sujeito procura enunciar alguma coisa para alguém, pela qual espera que o seu dizer seja devidamente captado pelo outro. Vale dizer, o sujeito fala pelo seu sintoma, numa palavra que é certamente balbuciante e plena de murmúrios, mas mesmo assim algo que é da ordem da palavra, de fato e de direito. Desta maneira, o sintoma fala, delineando um apelo do sujeito dirigido ao outro.

Um dos méritos maiores da constituição da psicanálise, com Freud, foi justamente o de ter reconhecido a existência deste apelo na estrutura do sintoma, quando toda a tradição médica e psiquiátrica que lhe antecedera, no século XIX, colocava em destaque a negatividade semântica do sintoma. Com efeito, o discurso freudiano conferiu positividade ao sintoma. Foi justamente por conta disso que Freud ([1900] 1967) passou a realizar o deciframento do sintoma, para colocar em evidência o que o sujeito procurava dizer no seu murmúrio e possibilitar, assim, que o que era balbuciado pudesse ser dito em plena voz, para se tornar então audível.

O que Freud pôde então descobrir foi a existência da divisão no psiquismo, marcado pela conflitualidade, de forma que seria pela solução de compromisso entre imperativos opostos que o sintoma se cristalizaria. Promover a dissolução desse cristal sintomático e deixar fluir as forças opostas seria, portanto, a condição de possibilidade para que o sujeito pudesse enunciar o seu desejo (Freud, [1900] 1967).

Nesta perspectiva, seria necessário que alguém pudesse acolher e receber a mensagem cifrada do sujeito para que o desejo latente no sintoma pudesse ser dito 
e escutado. Vale dizer, se não existir este outro no polo da recepção da mensagem, o murmúrio que se encontra latente no sintoma ficará silencioso. Portanto, a interlocução com o outro não se processa necessariamente no registro do sintoma, de maneira que a cena psíquica não se desdobra imediatamente na cena social e na cena da interlocução.

No entanto, no que concerne ao lapso, as coisas se passariam de maneira diferente. Com efeito, no lapso o sujeito acaba por falar algo que supostamente não queria enunciar, na sua elocução. Vale dizer, o sujeito diz algo para um outro à sua revelia, algo que não poderia ser enunciado e que seria mais forte no seu imperativo do que o sujeito gostaria que fosse. Porém, se foi efetivamente dito e não apenas balbuciado, o sujeito pode reconhecer a contragosto que queria dizer algo, apesar dele mesmo. Vale dizer, no lapso a realização do desejo se materializaria no campo do diálogo com o outro, de maneira que a cena psíquica e a cena social também se conjugariam.

No ato falho a mesma coisa se realizaria de maneira ainda mais radical. Isso porque no ato falho uma ação se realiza e essa atinge o outro de forma frontal. $\mathrm{O}$ corpo do sujeito e o corpo do outro se encontrariam diretamente, de maneira a se conjugarem numa cena eminentemente social. Vale dizer, o desejo que se inscrevia inicialmente na cena psíquica se desdobraria na cena social sob a forma de uma ação efetiva.

No sonho, contudo, as coisas se passam de maneira diferente do que ocorre no lapso e no ato falho. Assim, a realização do desejo se faz aqui de maneira oblíqua, pela mediação de sequências de imagens que seriam aparentemente desconjuntadas, num cenário caracterizado pela surrealidade. É claro que o sujeito diz algo na experiência do sonho, mas de forma eminentemente cifrada, de modo que não se dá conta da realização de desejo que coloca em pauta na cena psíquica.

Assim, no sonho o sujeito ocupa uma posição eminentemente solipsista, sem que o outro a quem se dirige, na Outra cena, possa se fazer presente. Desta maneira, a cena psíquica não se desdobraria numa cena social e não se conjugaria com essa. Além disso, o sujeito não quer reconhecer o desejo que se realizaria efetivamente na cena psíquica, pois o transveste imageticamente de maneira surreal.

A experiência do pesadelo confirma a veracidade de tal formulação. Assim, como no pesadelo a realização de desejo se manifesta de maneira franca e explícita, o sujeito acorda, assustado, tomado pela angústia de corpo inteiro. Por isso mesmo desperta imediatamente, para interromper o sonho e silenciar o que acabara de ser enunciado de maneira audível e mesmo brutal (Freud, [1900] 1967).

A piada se aproximaria, assim, do ato falho e do lapso no que concerne à conjunção da cena psíquica e da cena social, mas tal conjunção se realizaria de maneira 
ainda mais radical naquela. Na piada, com efeito, o sujeito pretende realizar o seu desejo em voz alta, sem qualquer disfarce ou opacidade. Quer depreciar alguém, ridicularizando intencionalmente um outro, ao contar uma piada sobre esse para um interlocutor. Com a gargalhada irônica, o gozo se disseminaria na cena social, numa atmosfera coletiva de festa que é feita às custas de quem é ironizado. Enfim, a piada e o humor se inscreveriam efetivamente no registro da transgressão, o que os caracterizaria enquanto formas de discursividade.

\section{CONTRAPODER}

Seria justamente por conta disso que a cena política se destacou, no campo da cena social, como o alvo privilegiado do humor e da piada, na modernidade, na medida em que tais modalidades de discurso passaram a ser interditadas. Assim, desde a Antiguidade grega e romana até o século XVIII, o humor e a piada circulavam no espaço social com relativa liberdade. No final do século XVIII, contudo, uma transformação crucial se realizou efetivamente. Passou-se a conceber desde então que tais práticas discursivas não seriam bem educadas, marcadas que seriam pelo mau gosto e pela vulgaridade. Em decorrência disso, passaram a ser socialmente mal apreciadas e não valoradas no espaço público, o que as conduziu inequivocamente à interdição simbólica (Elias, 1994; Skinner, 2002).

Assim, se o poder interpretava negativamente o humor e a piada como signos que seriam da grosseria e da má educação, desde o final do século XVIII o humor e a piada, em contrapartida, passaram a se disseminar no espaço social como formas de contrapoder. Desbancar ironicamente os detentores do poder político assim como ridicularizar as outras modalidades de poder social evidenciadas pelas hierarquias instituídas passaram a ser os campos privilegiados para as práticas do humor e da piada. Enfim, promover insistentemente a dimensão do ridículo, presente nos personagens que exerciam o poder, passou a ser o alvo por excelência de tais práticas discursivas.

Foi por conta disso, portanto, que o discurso freudiano delineou a piada e o humor na perspectiva de serem efetivamente formações do inconsciente, indicando, assim, ao mesmo tempo, como foram interditadas simbolicamente e como se enunciariam em contrapartida como formas de realização de desejo pela via do retorno do recalcado, como se passaria, aliás, com todas as demais formações do inconsciente. Enfim, mostrar insistentemente que o Rei está nu, seja o Rei uma das figuraçōes do poder político, seja uma das figurações presentes nas hierarquias 
sociais, passou a ser uma poderosa forma de realização de desejo, que se inscrevia no campo do espaço público.

Porém é preciso evocar ainda que o interesse de Freud pela problemática do humor e da piada se realizou pelo viés de um campo social e político bem específico, constituído pela problemática do antissemitismo. Foram o humor e a piada, forjados pela tradição judaica sobre o antissemitismo, o que conduziu Freud a se interrogar efetivamente sobre tais práticas discursivas, indagando-se o que se pretendia com tais experiências, afinal das contas.

Assim, Freud passou a se interessar pelas piadas antissemitas, num repertório bem particular e específico, que pode nos parecer inicialmente paradoxal. Com efeito, as piadas antissemitas que interessavam a Freud eram as que eram forjadas pelos próprios judeus e não pelos antissemitas. Isso é um acontecimento no mínimo curioso, na medida em que os judeus disseminavam piadas antissemitas no espaço social e gargalhavam ostensivamente com as piadas que inventavam, para assim se autoironizarem.

Deste modo, na sua correspondência com Fliess nos tempos heroicos da constituição da psicanálise, Freud ([1887-1902] 1973) fazia frequente alusão a piadas, inserindo-as literalmente no campo de uma séria discussão científica. Dentre estas, as piadas antissemitas, forjadas por judeus, eram as mais frequentes na escrita de Freud. Fliess não entendia bem a razão disso, estranhando o procedimento desse. A resposta final de Freud à estranheza de Fliess foi a elaboração de uma longa obra sobre os chistes, pela qual o discurso freudiano formulou uma teoria sobre a piada, inscrevendo essa no campo das formações do inconsciente.

Nesta perspectiva, o discurso freudiano procurava realizar a desconstrução do antissemitismo, ironizando as formas pelas quais o antissemitismo atacava a tradição judaica. Com isso, o discurso freudiano procurou realizar a leitura do proverbial humor judaico, indicando como, através da autoironia, os judeus procuravam desconstruir as bases éticas e políticas do antissemitismo. Isso porque não se inscreviam na posição masoquista e melancólica das vítimas, mas procuravam dar a volta por cima dos ataques que sofriam pela autoironia. Vale dizer, pelo humor judaico e a produção em cascata de piadas antissemitas, a tradição judaica realizava de maneira insistente práticas de contrapoder para desconstruir em ato o poder do antissemitismo, que pretendia destruir o judaísmo como tradição cultural, social e religiosa.

Desta maneira, não é um acaso que as duas grandes obras sobre o humor e a piada, que foram forjadas na aurora do século XX, O riso de Bergson ([1900] 1983) e $O$ chiste e suas relaçôes com o inconsciente de Freud ([1905] 1969), foram produzidas no campo social da tradição judaica. Com efeito, no contexto antis- 
semita do processo Dreyfuss, na França, e no contexto antissemita de Viena, no início do século passado, Bergson e Freud respondiam ao discurso antissemita pela evocação do humor judaico e pela promoção teórica da piada como forma efetiva de contrapoder.

Portanto, a valoração do chiste, realizada pelo discurso freudiano, retomou uma antiga tradição filosófica, ética e crítica que remete à Antiguidade grega e romana e que se desenvolveu muito na Idade Média e no Renascimento, como as pesquisas de Bakhtin (1970) demonstraram de maneira consistente. De forma que é preciso sempre rir e produzir chistes cotidianamente para desconstruir os interditos instituídos pelo poder, para que o sujeito possa assim afirmar o seu desejo e restaurar então certos direitos, para manter os valores de sua tradição simbólica e a integridade política de sua comunidade social. Foi assim que fizeram Freud e Bergson, em face do antissemitismo francês e austríaco na virada do século XIX para o século XX, e Bakhtin, no que concerne à opressão presente na Uniāo Soviética, na época da tirania stalinista. Enfim, desta maneira a figura do Rei nu é ironicamente mostrada e ridiculamente escancarada no espaço público, para a gargalhada ampla, geral e irrestrita de todos, que com isso restauram a condição fundamental da moderna cidadania.

\section{REFERÊNCIAS}

Bakhtin, M. (1970). L'oeuvre de Rabelais et la culture populaire au moyen âge et sous la Renaissance. Paris: Seuil.

Bergson, H. (1900/1983). Le rire. Paris: PUF.

Elias, N. (1994). O processo civilizatório. Rio de Janeiro: Zahar.

Freud, S. (1887-1902/1973). Lettres a Wilhelm Fliess, notes et plans. In: La naissance de la psychanalyse (pp. 100-170). Paris: PUF.

Freud, S. (1895/1973). Esquisse d'une psychologie scientifique. In: La naissance de la psychanalyse (pp. 336-349). Paris: PUF.

Freud, S. (1896/1973). Les psychonévroses de défense. In: Névrose, psychose et perversion (pp. 1-14). Paris: PUF.

Freud, S. (1900/1967). Linterprétation des rêves. Paris: PUF.

Freud, S. (1901/1973). Psychopathologie de la vie quotidienne. Paris: Payot.

Freud, S. (1905/1962). Trois essais sur la théorie de la sexualité. Paris: Gallimard.

Freud, S. (1905/1969). Le mot d'esprit et ses rapports avec l'inconscient. Paris: Gallimard.

Freud, S. (1920/1987). Au-delà du principe du plaisir. In: Essais de psychanalyse (pp. 41115). Paris: Payot. 
Lacan, J. (1953/1966). Fonction et champ de la parole et du langage en psychanalyse. In: Écrits (pp. 270). Paris: Seuil.

Nietzsche, F. (1878/1968). Humain, trop humain. Paris: Gallimard.

Skinner, Q. (2002). Hobbes e a teoria clássica do riso. São Leopoldo: Unisinos.

Recebido em 09 de março de 2010 Aceito para publicação em 20 de abril de 2010 